\title{
Redox potential and survival of virulent Treponema pallidum under microaerophilic conditions
}

\author{
B STEINER, I MCLEAN, AND S GRAVES \\ From the Department of Microbiology, Monash University Medical School, Alfred Hospital, Prahran, \\ Victoria, Australia
}

SUMMARY A strongly reduced culture medium, capable of maintaining the virulence of Treponema pallidum (Nichols) for several days, was exposed to an atmosphere of 3\% oxygen in nitrogen for 2-3 days before inoculation with $T$ pallidum. By using various volumes of medium in uniform tubes a range of redox potentials $\left(E_{c a l}\right)$ from $-94 \mathrm{mV}$ to $-325 \mathrm{mV}$ was produced depending on the surface area-to-volume ratios of the medium. The anaerobic medium had an $\mathrm{E}_{\mathrm{cal}}$ value of $-387 \mathrm{mV}$.

The medium was inoculated with $T$ pallidum and incubated in an atmosphere of $3 \%$ oxygen. The survival of treponemes at different redox potentials was monitored by observing the retention of motility and by measuring the latent period of infection after inoculation of the cultures into the shaved backs of rabbits.

Under these conditions $T$ pallidum survived longest at low (electronegative) redox potential. An inverse linear relationship was observed between the redox potential of the culture medium and the survival of $T$ pallidum, as measured by the time required for a $90 \%$ reduction of virulent organisms. No optimum redox potential was detected, the most electronegative medium $\left(-325 \mathrm{mV}, \mathrm{E}_{\mathrm{cal}}\right)$ giving the best survival.

\section{Introduction}

Despite an effort extending over 70 years successful cultivation of $T$ pallidum in vitro has not been achieved (see Addendum), although several laboratories have recently reported slight but notable growth of this pathogen. ${ }^{2} 2$ The difficulties of in-vitro cultivation have limited at tempts to develop a vaccine against syphilis. Present research has included studies of the short-term metabolism of $T$ pallidum in the hope of establishing conditions under which sustained growth of this bacterium in vitro could be obtained.

$T$ pallidum was previously considered to be an obligate anaerobe. The demonstration in recent years of oxygen consumption similar to an aerobic Leptospira, ${ }^{3}$ the presence of a functional cytochrome system, ${ }^{34}$ and oxidative phosphorylation ${ }^{5}$ have indicated the aerophilic character of the organism. Degradation of glucose and pyruvate, ${ }^{6}{ }^{7}$

Address for reprints: Dr B Steiner, Department of Microbiology, Monash University Medical School, Alfred Hospital, Prahran, Victoria 3181, Australia

Accepted for publication 29 March 1981 incorporation of amino acids into protein, ${ }^{8}$ uridine into nucleic acids, ${ }^{9}{ }^{10}$ and glucose into TCA precipitable material," and decarboxylation of pyruvate $^{12}$ all occurred under aerobic conditions, although some studies have also shown anaerobic metabolism. ${ }^{13} 14$

The optimum concentration of oxygen for $T$ pallidum metabolism has been determined by monitoring its survival under varying concentrations of atmospheric oxygen. Using a tissue culture system Fieldsteel et al ${ }^{15}$ established an oxygen gradient in which maximum survival ( 21 days) was observed in a region neither fully aerobic nor anaerobic. Under microaerophilic conditions ( $2 \cdot 5 \%$ oxygen) Fitzgerald et $a l^{16}$ were able to demonstrate prolonged retention of virulence and the synthesis of treponemal surface acid mucopolysaccharide in a tissue culture system. Recently, Graves and Billington ${ }^{17}$ examined the survival of $T$ pallidum in a cell-free system under a range of dissolved oxygen concentrations from $0.7 \%$ to $12 \cdot 6 \%$ (atmcspheric equivalents). Maximum survival was seen at $3 \%$ oxygen. Norris et al ${ }^{18}$ found $3 \%$ oxygen to be superior to either strictly anaerobic or aerobic conditions. That oxygen was a mixed blessing for $T$ pallidum was demonstrated by the 
requirement for reducing agents for survival under microaerophilic conditions. ${ }^{18}$ Research using strictly anaerobic conditions indicated that the retention of motility by $T$ pallidum required a highly reduced environment. ${ }^{19} T$ pallidum is now known to be much less active metabolically under anaerobic conditions. ${ }^{20}$ The present study was undertaken to determine the optimum conditions of oxidationreduction potential for the retention of virulence in $T$ pallidum under what is now considered to be the optimum level of oxygen in the atmosphere above the culture medium $(3 \%)$.

\section{Materials and methods}

MAINTENANCE OF TPALLIDUM

Adult male rabbits were used for the propagation of $T$ pallidum (Nichols). They were inoculated with $5 \times 10^{7}$ treponemes per testis. An orchitis usually developed in 11 days. The rabbit was killed by intravenous injection of $3 \mathrm{ml}$ of sodium pentobarbitone $(200 \mathrm{mg} / \mathrm{ml})$, and the testes were minced and eluted with six successive $10-\mathrm{ml}$ aliquots of reduced medium under aerobic conditions. The extraction period was approximately 30 minutes. The first $10 \mathrm{ml}$ were discarded since they contained large amounts of tissue debris and erythrocytes. The yield was approximately $50 \mathrm{ml}$ of inoculum with a concentration of approximately $10^{7}$ treponemes $/ \mathrm{ml}$. These bacteria were used immediately as inoculum for the tubes of medium at various redox potentials (see below), $10 \%$ of the medium volume being added as inoculum giving a final concentration of approximately $10^{6}$ treponemes $/ \mathrm{ml}$.

\section{PREPARATION OF REDUCED MEDIUM}

The medium was a modification of that used by Graves and Billington. ${ }^{17}$ It was prepared in two parts (A and B) as shown in table I. Part A was prereduced (before the addition of reducing agents and HEPES buffer) by autoclaving at $121^{\circ} \mathrm{C}$ for eight minutes followed by slow exhaust. It was cooled under sterile oxygen-free nitrogen and the reducing agents and HEPES buffer added as powders and dissolved by stirring. The medium was adjusted to $\mathrm{pH} 7 \cdot 6-7 \cdot 7$ with $10 \mathrm{~mol} / 1 \mathrm{NaOH}$, the flask tightly stoppered, placed in a clamp, and sterilised by autoclaving at $121{ }^{\circ} \mathrm{C}$ for 15 minutes followed by fast exhaust.

Part B was prepared from solutions sterilised separately by filtration (amino acids, vitamins, solution D) or autoclaving (fructose, glucose, and phosphate solutions). When part $\mathrm{A}$ had cooled to ambient temperature part B (excluding glutamine and solution D) was added under sterile nitrogen. The final $\mathrm{pH}$ was $7 \cdot 2-7 \cdot 4$. Ten-millilitre aliquots were dispensed into nitrogen flushed tubes (Bellco)
TABLE I Composition of reduced medium

\begin{tabular}{|c|c|}
\hline Components & $\begin{array}{l}\text { Amount } / 1 \\
\text { (final total } \\
\text { medium) }\end{array}$ \\
\hline $\begin{array}{l}\text { Part A } \\
\text { Balanced salt solution concentrate* } \\
\left(\mathrm{NH}_{4}\right)_{2} \mathrm{SO}_{4}(50 \mathrm{~g} / \mathrm{l}) \\
\mathrm{H}_{2} \mathrm{O} \\
\text { HEPES buffert } \\
\text { Glutathione (reduced) } \\
\text { Cysteine } \\
\text { Sodium thioglycolate }\end{array}$ & $\begin{array}{r}60 \mathrm{ml} \\
2 \mathrm{ml} \\
614 \mathrm{ml} \\
7.15 \mathrm{~g} \\
2.38 \mathrm{~g} \\
1.58 \mathrm{~g} \\
1.00 \mathrm{~g}\end{array}$ \\
\hline $\begin{array}{l}\text { Part B } \\
\text { Glucose } \neq \\
\text { Fructose } \neq \\
\text { Glutamine }(29 \cdot 2 \mathrm{~g} / \mathrm{l}) \\
\text { Amino acid concentrate A } \$ \\
\text { Amino acid concentrate B\| } \\
\text { Amino acid concentrate C } \\
\text { Vitamin concentrate** } \\
\text { Solution D+t } \\
\text { Fetal calf serum (heat inactivated) }\end{array}$ & $\begin{array}{l}1.60 \mathrm{~g} \\
1.60 \mathrm{~g} \\
10 \mathrm{ml} \\
10 \mathrm{ml} \\
10 \mathrm{ml} \\
10 \mathrm{ml} \\
10 \mathrm{ml} \\
10 \mathrm{ml} \\
250 \mathrm{ml}\end{array}$ \\
\hline
\end{tabular}

${ }^{*} \mathrm{NaCl}(40 \mathrm{~g} / \mathrm{l}), \mathrm{KCl}(4 \mathrm{~g} / \mathrm{l}), \mathrm{CaCl}_{2}(1.4 \mathrm{~g} / \mathrm{l}), \mathrm{Na}_{2} \mathrm{HPO}_{4}(0.6 \mathrm{~g} / \mathrm{l})$. $\mathrm{KH}_{2} \mathrm{PO}_{4}(0.6 \mathrm{~g} / \mathrm{l}), \mathrm{MgSO}_{4} 7 \mathrm{H}_{2} \mathrm{O}(2 \mathrm{~g} / \mathrm{l})$.

$+\mathrm{N}$-2-Hydroxyethylpiperazine $-\mathrm{N}^{1}$-2-ethanesulfonic acid (HEPES) \#Added as sterile $50 \%$ solutions.

§Composition per $10 \mathrm{ml}$ : arginine $\mathrm{HCl}, 105 \mathrm{mg}$; histidine $\mathrm{HCl} \mathrm{H}_{2} \mathrm{O}, 31 \mathrm{mg}$ : isoleucine, $52 \mathrm{mg}$; leucine, $52 \mathrm{mg}$; lysine $\mathrm{HCl}$, $58 \mathrm{mg}$; methionine, $15 \mathrm{mg}$; phenylalanine, $32 \mathrm{mg}$; threonine, $48 \mathrm{mg}$; tryptophan, $10 \mathrm{mg}$; and valine, $46 \mathrm{mg}$.

$\|$ Composition per $10 \mathrm{ml}$; cystine, $24 \mathrm{mg}$ and tyrosine, $36 \mathrm{mg}$

IComposition per $10 \mathrm{ml}$ : alanine, $8.9 \mathrm{mg}$; asparagine $\mathrm{H}_{2} \mathrm{O}, 15 \mathrm{mg}$; aspartic acid, 13.3 mg; glutamic acid, $14.7 \mathrm{mg}$; proline, $11.5 \mathrm{mg}$; serine, $10.5 \mathrm{mg}$; and glycine, $7.5 \mathrm{mg}$.

** Composition per $10 \mathrm{ml}$ : choline chloride, $1 \mathrm{mg}$; folic acid, $1 \mathrm{mg}$; i-inositol, $2 \mathrm{mg}$; nicotinamide, $1 \mathrm{mg}$; calcium pantothenate, $1 \mathrm{mg}$; pyridoxal $\mathrm{HCl}, 1 \mathrm{mg}$; riboflavin, $0.1 \mathrm{mg}$; and thiamine $\mathrm{HCl}, 1 \mathrm{mg}$. t+Composition per $10 \mathrm{ml}$ : sodium pyruvate, $250 \mathrm{mg}$; adenine, $5 \mathrm{mg}$; cocarboxylase, $3 \mathrm{mg}$; coenzyme A, $50 \mu \mathrm{g}$; isobutyric acid, $10 \mathrm{mg}$; $\alpha$-lipoic acid, $5 \mathrm{mg}$; p-amino benzoic acid, $5 \mathrm{mg}$; biotin $50 \mu \mathrm{g}$; nicotinic acid, $500 \mu \mathrm{g}$; pyridoxine $\mathrm{HCl}, 2.5 \mathrm{mg}$; pyridoxamine $\mathrm{HCl}, 5 \mathrm{mg}$; putrescine $2 \mathrm{HCl}, 10 \mathrm{mg}$; and cyanocobalamin, $50 \mu \mathrm{g}$; uracil $5 \mathrm{mg}$; folinic acid $0.8 \mathrm{mg}$; and pyridoxal phosphate $1 \mathrm{mg}$.

and tightly stoppered. These became the anaerobic control tubes. The remainder of the medium was placed in an anaerobic hood (Germ Free Laboratories) under an atmosphere of $3 \%$ oxygen in nitrogen and dispensed into sterile glass tubes (Corex, $150 \times 23 \mathrm{~mm}, 50-\mathrm{ml}$ volume). A redox gradient was established by placing varying volumes of medium into the tubes and allowing them partially to equilibrate with the $3 \%$ oxygen atmosphere. The range of surface-to-volume ratios resulted in different degrees of oxidation of the medium by the $3 \%$ oxygen atmosphere. The volumes used were 3,5 , 10,20 , and, in some experiments, $7 \mathrm{ml}$, giving surface-to-volume ratios of $1 \cdot 38,0 \cdot 83,0 \cdot 42,0 \cdot 21$, and 0.59 respectively. The tubes, with cottonwool plugs, were allowed to remain at $34^{\circ} \mathrm{C}$ for 2-3 days before inoculation with freshly harvested $T$ pallidum. Immediately before inoculation glutamine and solution $\mathrm{D}$ were added to each individual tube because of the chemical instability of certain components of each of these additives. 


\section{MEASUREMENT OF DISSOLVED OXYGEN} CONCENTRATION

An oxygen meter (Model LR-30, Titron Australia, Melbourne), fitted with a Clark-type oxygen electrode modified to allow measurements in static solutions, was used. The meter gave readings in "parts per million" ( $\mu \mathrm{g} / \mathrm{l})$ dissolved oxygen in water. The electrode was calibrated at $34^{\circ} \mathrm{C}$ with $100 \%$ nitrogen (oxygen-free), $3 \%$ oxygen in nitrogen and air, giving a linear relationship between oxygen meter reading $(\mu \mathrm{g} / \mathrm{l})$ and oxygen concentration in the gases as previously shown. ${ }^{17}$ Since the media in which dissolved oxygen concentration was being measured had been exposed to an atmosphere of $3 \%$ oxygen for two or three days, the calibration of the electrode with these three oxygen/nitrogen gas mixtures was considered satisfactory, although we appreciated that the electrode-based measurements of the culture media were not as accurate as a chemical determination of dissolved oxygen concentration. (The dissolved oxygen concentrations given in table II correspond to the equivalent percentage of oxygen in the atmosphere above the medium.)
MEASUREMENT OF REDOX POTENTIAL

The redox potential of the medium was determined with a Platinum-Calomel electrode. ${ }^{17}$ Tubes were stoppered before removal from the $3 \%$ oxygen hood and kept closed until the redox electrode was inserted for redox measurement. Duplicate samples were measured at each determination.

DETERMINATION OF VIABILITY OF TPALLIDUM Survival of $T$ pallidum was monitored by determining motility and virulence. Motility was determined by darkfield microscopical examination of 50 randomly selected treponemes from each of a pair of tubes at a given sample time and the percentage of actively motile treponemes recorded. Virulence was determined by inoculating the $T$ pallidum samples into rabbits. Before removal from the $3 \%$ oxygen atmosphere, $0.8 \mathrm{ml}$ of the sample to be tested was placed in a $1-\mathrm{ml}$ syringe and $0.4 \mathrm{ml}$ immediately inoculated into the shaved backs of each of two male rabbits. The backs of the rabbits had been previously divided into a $4 \times 5$ grid of $2 \cdot 5 \mathrm{~cm}$ squares, and for each sample $0 \cdot 1 \mathrm{ml}$ was inoculated into each of four

TABLE II The relationship between volume of medium per tube, redox potential of the medium, percentage of motile $T$ pallidum, and the virulence of $T$ pallidum present in the medium over the three-day experimental period*

\begin{tabular}{|c|c|c|c|c|c|}
\hline \multirow[b]{2}{*}{$\begin{array}{l}\text { Time } \\
\text { (hours) }\end{array}$} & \multirow{2}{*}{$\begin{array}{l}\text { Medium } \\
\text { volume } \\
(\mathrm{ml})\end{array}$} & \multirow{2}{*}{$\begin{array}{l}\text { Redox } \\
\text { potential† } \\
(m V)\end{array}$} & \multirow{2}{*}{$\begin{array}{l}\text { Dissolved } \\
\text { oxygen (\%) } \\
\text { (atmospheric } \\
\text { equivalent) }\end{array}$} & \multicolumn{2}{|c|}{$T$ pallidum survival } \\
\hline & & & & $\begin{array}{l}\text { Motility } \\
(\%)\end{array}$ & Virulence $\neq$ \\
\hline 0 & $\begin{array}{l}3 \\
5 \\
10 \\
20 \\
\mathrm{AnO}_{2} \S\end{array}$ & $\begin{array}{l}-171 \\
-207 \\
-282 \\
-305 \\
-397\end{array}$ & $\begin{array}{l}3 \cdot 2 \\
2 \cdot 4 \\
2 \cdot 0 \\
1 \cdot 8 \\
0 \cdot 4\end{array}$ & $\begin{array}{l}100 \\
100 \\
100 \\
100 \\
100\end{array}$ & $\begin{array}{l}1.11 \\
1.06 \\
0.99 \\
1.00 \\
1.05\end{array}$ \\
\hline 24 & $\begin{array}{l}3 \\
5 \\
10 \\
20 \\
\mathrm{AnO}_{2}\end{array}$ & $\begin{array}{l}-121 \\
-179 \\
-282 \\
-330 \\
-380\end{array}$ & $\begin{array}{l}3 \cdot 2 \\
3 \cdot 1 \\
2 \cdot 6 \\
2 \cdot 5 \\
1 \cdot 1\end{array}$ & $\begin{array}{l}20 \\
28 \\
38 \\
49 \\
80\end{array}$ & $\begin{array}{l}1.40(12 / 20) \| \\
1.23(16 / 20) \| \\
0.97 \\
1.00 \\
0.73\end{array}$ \\
\hline 48 & $\begin{array}{l}3 \\
5 \\
10 \\
20 \\
\mathrm{AnO}_{2}\end{array}$ & $\begin{array}{l}-102 \\
-158 \\
-270 \\
-323 \\
-367\end{array}$ & $\begin{array}{l}3 \cdot 6 \\
3 \cdot 2 \\
2 \cdot 4 \\
2 \cdot 4 \\
0 \cdot 7\end{array}$ & $\begin{array}{r}0 \\
11 \\
19 \\
21 \\
72\end{array}$ & $\begin{array}{l}\mathrm{NL} \\
1.40 \\
1.05 \\
1.00 \\
0.65\end{array}$ \\
\hline 72 & $\begin{array}{l}3 \\
5 \\
10 \\
20 \\
\mathrm{AnO}_{2}\end{array}$ & $\begin{array}{l}-75 \\
-114 \\
-255 \\
-345 \\
-399\end{array}$ & $\begin{array}{l}2 \cdot 9 \\
2 \cdot 4 \\
1 \cdot 6 \\
2 \cdot 0 \\
0 \cdot 6\end{array}$ & $\begin{array}{r}0 \\
0 \\
0 \\
5 \\
55\end{array}$ & $\begin{array}{l}N L \\
N L \\
N L \\
1 \cdot 00 \\
0 \cdot 79\end{array}$ \\
\hline
\end{tabular}

* Averaged data from six independent experiments.

tDaily readings given in table. The mean values over the three-day experimental period were: $3 \mathrm{ml}:-94 \mathrm{mV} ; 5 \mathrm{ml}:-166 \mathrm{mV} ; 10 \mathrm{ml}:-268 \mathrm{mV}$; $20 \mathrm{ml}:-325 \mathrm{mV}$; and $\mathrm{AnO}_{2}:-387 \mathrm{mV}$.

₹Expressed as the ability of the sampled $T$ pallidum to cause syphilitic lesions on rabbits compared with treponemes in the 20 -ml medium sample. Calculated as the mean latent period of infection of the sample divided by the mean latent period of infection produced by the 20 -ml tube sample. Numbers $>1$ indicate longer latent periods and consequently fewer virulent $T$ pallidum present than in the 20 -ml sample. Latent period is the time (in days) between rabbit inoculation and the appearance of syphilitic induration at the inoculation site.

\$Anaerobic control; volume irrelevant.

IDenominator: total number of inoculated sites on rabbits; numerator: number of inoculated sites that developed into syphilitic lesions.

Unless otherwise stated all sites developed into lesions.

$\mathrm{NL}=$ No lesions developed from any inoculated sites. 
sites on the grid. The samples from media with different redox potentials were inoculated into different rows on the back of the same rabbit. Duplicate rabbits were inoculated at each time sample to minimise any effects of individual variations in their susceptibility to $T$ pallidum. A total of eight rabbits was used for each experiment. The rabbits were kept cool $\left(18^{\circ} \mathrm{C}\right)$, shaved, and examined daily for the appearance of induration at the site of inoculation. The number of virulent $T$ pallidum in the sample was determined from the latent period of the infection using a standard curve. $^{21}$

\section{Results}

\section{GENERATION OF A RANGE OF REDOX}

POTENTIALS

With the method used the survival of $T$ pallidum was tested in a range of redox potentials. The results of six separate experiments (averaged) are given in table II. Under the $3 \%$ oxygen atmosphere, concentrations of dissolved oxygen equivalent to between $1 \cdot 8 \%$ and $3 \cdot 2 \%$ atmospheric oxygen were present in the tubes of medium at the start of the experiment, depending on the particular surface-to-volume ratio, while the redox potentials ranged from $-171 \mathrm{mV}$ to $-305 \mathrm{mV}$ (table II).

\section{EFFECT OF REDOX POTENTIAL ON T PALIIIDUM} SURVIVAL

Survival of $T$ pallidum as monitored by both motility and virulence under various redox conditions is shown in table II and fig 1.

Survival times were longest in tubes which were the most electronegative. Survival was considerably better in the anaerobic control than would have been expected by virtue of its lower redox potential (see Discussion). Survival was markedly diminished in the 3- $\mathrm{ml}$ and 5-ml tubes where the redox potential was more electropositive than $-200 \mathrm{mV}$ (Ecal) (table II). This was also shown by the marked delay in lesion formation following inoculation of treponemes into rabbits after only short incubation periods in vitro at these redox potentials. A typical example of one such experiment is given in table III. In two other experiments no viable treponemes were observed in media more electropositive than $-150 \mathrm{mV}$ ( $\mathrm{E}_{\mathrm{cal}}$ ) after only 24 hours' incubation in vitro.

Overall, an inverse linear relationship between the redox potential of the culture medium (under $3 \%$ oxygen) and the survival of virulent $T$ pallidum was observed when treponemal survival was measured as the time (in hours) required for a $90 \%$ fall in the concentration of viable $T$ pallidum in the culture (fig 2).

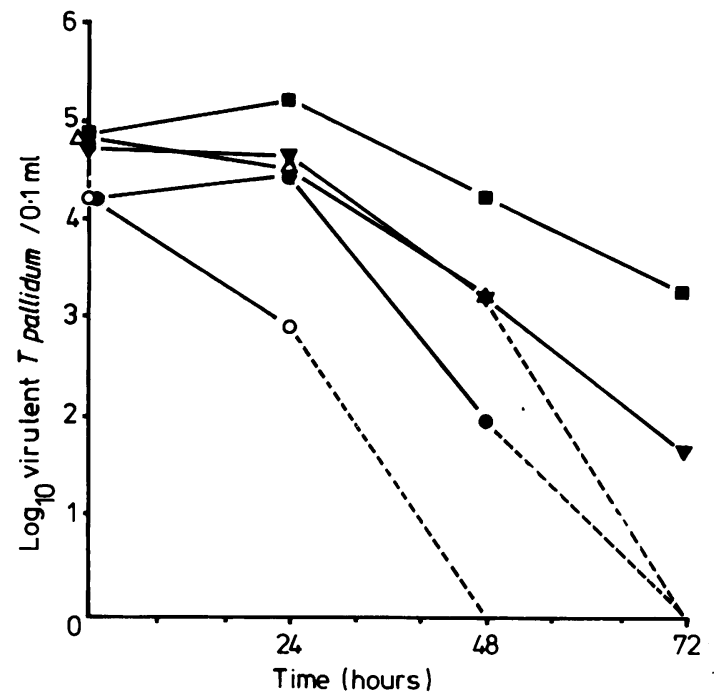

FIG 1 The fall in concentration of virulent $T$ pallidum (per $0.1 \mathrm{ml}$ ) in media with different redox potentials: anaerobic tubes: average redox potential, $-387 \mathrm{mV}$ $\left(E_{c a l}\right) ; \Delta 20-\mathrm{ml}$ tubes: average redox potential, $-325 \mathrm{mV}$ $\left(E_{\text {cal }}\right) ; \quad \nabla 10-\mathrm{ml}$ tubes: average redox potential, $-268 \mathrm{mV}$ $\left(E_{\text {cal }}\right) ;$ 5-ml tubes: average redox potential, - $166 \mathrm{mV}$ ( $\left.E_{c a l}\right) ;$ and $\bigcirc$ 3-ml tubes: average redox potential, $-94 \mathrm{~m}$ (Ecal).

\section{Discussion}

The oxygen concentration and the redox potential of the medium can be of great importance to anaerobic and microaerophilic organisms which have little capacity for controlling the toxic effects of oxygen on the living cell. 22 In this study with $T$ pallidum incubated in vitro we have found a clear relationship between treponemal survival and the redox potential of the medium at low oxygen concentrations $(\leqslant 3 \%)$. The more electropositive the medium, the poorer was the survival of $T$ pallidum in the cell-free medium

TABLE III The virulence of $T$ pallidum removed after one hour in culture medium with different redox potentials under microaerophilic conditions.

\begin{tabular}{lll}
\hline $\begin{array}{l}\text { Volume of medium } \\
(\mathrm{ml})\end{array}$ & $\begin{array}{l}\text { Redox potential } \\
(\mathrm{mV})\end{array}$ & $\begin{array}{l}\text { Latent period of lesion } \\
\text { formation }(\text { days })^{*}\end{array}$ \\
\hline 3 & -152 & $17 \cdot 0$ \\
5 & -168 & $15 \cdot 3$ \\
7 & -230 & $9 \cdot 5$ \\
10 & -252 & $8 \cdot 4$ \\
20 & -271 & $8 \cdot 6$ \\
\hline
\end{tabular}

*Latent period is the time (in days) between rabbit inoculation and the appearance of syphilitic induration at the inoculation site. Longer latent periods indicate fewer virulent $T$ pallidum present in the inoculum. 


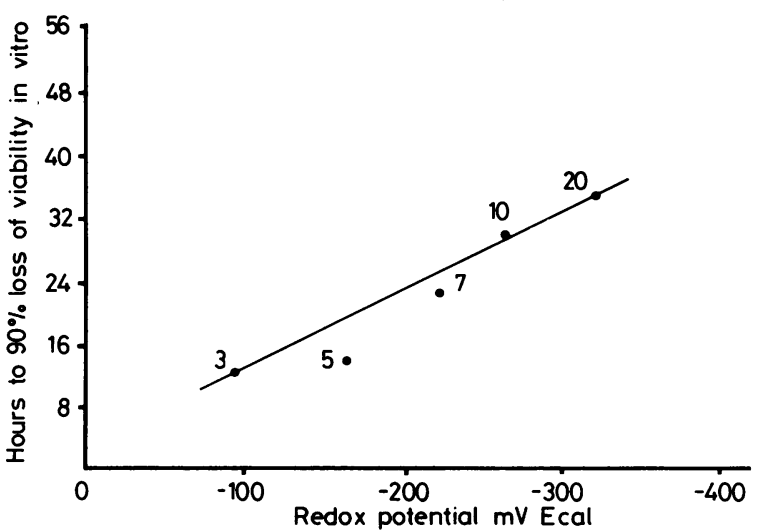

FIG 2 Inverse linear relationship between redox potential of culture medium (under $3 \%$ oxygen) and survival of virulent $T$ pallidum, as measured by the time required for the concentration of virulent $T$ pallidum to fall by $90 \%$. (Key: 3, 5, 7, 10, and 20=No of $\mathrm{ml}$ of medium per tube.)

used. The electropositive medium appeared to be toxic since a large proportion of the bacteria died within a few hours of exposure. Under strictly anaerobic conditions Metzger and Smogor, ${ }^{19}$ using retention of motility of $T$ pallidum as the criterion of survival, reported an optimum redox potential of $-240 \mathrm{mV}$ (Ecal). In our study using a different medium and microaerophilic conditions an inverse relationship between redox potential and survival was evident, but no optimum was observed (fig 2 ).

The effects of redox potential on treponemal survival could be explained either by the medium becoming toxic or by the lack of some component necessary for long-term survival. Toxicity of the medium would best explain the very rapid death of treponemes seen at redox potentials above approximately $-150 \mathrm{mV}$ (Ecal). With an in-vivo generation time estimated at 33 hours, ${ }^{23}$ it is very unlikely that nutrient deficiency would cause death in such a short period. The most probable explanation is the previous production of toxic substances ${ }^{24}$ (for example, superoxide anions, hydrogen peroxide, hydroxyl radicals, and singlet oxygen) from the action of oxygen on certain medium components. ${ }^{25} 26$ At more negative redox potentials molecular oxygen is not as readily available in the medium to cause production of these toxic compounds. Survival in the anaerobic control medium was noticeably better than predicted from fig 2 on the basis of its redox potential alone. This suggests that by-products of oxidation reactions may have been detrimental to the survival of $T$ pallidum under the microaerophilic conditions used.
Media with redox potentials more electronegative than $-150 \mathrm{mV}$ showed stationary periods of 24 hours, when the number of virulent $T$ pallidum remained almost constant, before the onset of a rapid decline in numbers (fig 1). This suggests that the bacterium was unable to synthesise some key compound during in-vitro incubation in this medium. The stationary period might be expected to be shorter in a more aerobic medium, since metabolism is more rapid in higher concentrations of oxygen $^{20}$ and thus leads to an earlier death due to the deficiency in some key compound. This may be more complicated than a simple absence of a nutrient or factor necessary for macromolecular synthesis, since a dependency on the host could mean that $T$ pallidum may have faulty transport systems that break down outside of the host. This phenomenon is seen with intracellular parasites such as the Rickettsia. ${ }^{27}$

The apparent preference of $T$ pallidum for a microaerophilic but strongly electronegative environment in vitro may be related to several observations concerning $T$ pallidum in vitro and in vivo. In vivo $T$ pallidum grows well in oxygenated actively metabolising tissues which would, by virtue of rapid oxygen consumption, be quite electronegative. Such tissues would also be microaerophilic, since although oxygen flows into them from the blood circulation it is being rapidly utilised by the metabolising cells. The actual extracellular $\mathrm{pO}_{2}$ surrounding most mammalian tissues is low. In the uninfected rabbit testis it is $11.6 \mathrm{mmHg}^{28}$ and in the human epidermis $5 \mathrm{mmHg}$ at $32^{\circ} \mathrm{C}$ epidermal temperature. ${ }^{29}$ Both microaerophilic conditions and electronegative redox potentials may well occur concurrently in those locations in vivo in which $T$ pallidum grows well, such as the germinal epithelium of the rabbit testis, ${ }^{30}$ the human fetus in utero, and granulating wound tissue of rabbits and humans. ${ }^{31} T$ pallidum, when inoculated intravenously into rabbits, showed a marked preference for localising in granulating wounds on the shaved back where active cell growth was apparent. ${ }^{31}$ Furthermore, the injury to the skin may have resulted in the redox potential becoming more electronegative and, as such, more suitable for the metabolism of $T$ pallidum. Injuries to other tissues have resulted in the development of more electronegative redox potentials. 3233

The curative effect of hyperbaric oxygen on rabbit syphilis ${ }^{34}$ may be explained in terms of rises in the redox potential of the animal tissues. Cater et $a^{35}$ have shown that the breathing of oxygen causes a rise in tissue redox potential, especially subcutaneous tissue.

Attachment of $T$ pallidum to tissue culture cells and its postulated intracellular location appears to be 
associated with prolonged survival in vitro. ${ }^{36} 37$ This may reflect conditions of optimum redox potential for $T$ pallidum at these sites. Coburn et $a l^{38}$ found the intracellular oxygen tension to be 4-6 $\mathrm{mmHg}$ and to remain constant over an extracellular range of 35-400 mm $\mathrm{mg}$ oxygen tension. A survey of published intracellular redox potentials by Shapiro ${ }^{39}$ showed that the $E_{h}{ }^{*}$ varied from $-240 \mathrm{mV}$ (based on lactate/pyruvate ratio) to $-285 \mathrm{mV}$ (based on oxidized/reduced pyridine nucleotide ratio) to $-307 \mathrm{mV}$ within the mitochondrion. These values are considerably more reduced than those obtained in our most reduced microaerophilic culture medium, where the $20-\mathrm{ml}$ tube averaged $-325 \mathrm{mV}$ ( $\left.\mathrm{E}_{\mathrm{cal}}\right)$ (table II) or $-84 \mathrm{mV}\left(\mathrm{E}_{\mathrm{h}}\right)$. Extracellular redox potentials have been determined by the insertion of platinum or gold electrodes into intact tissue. Cater et $a l^{35}$ found $\mathrm{E}_{\mathrm{h}}$ values of approximately $+250 \mathrm{mV}$ in muscle, $+130 \mathrm{mV}$ in testis, and $+90 \mathrm{mV}$ in brain (Ecal equivalents; $+9 \mathrm{mV} ;-111 \mathrm{mV}$, and $-151 \mathrm{mV}$ respectively). These extracellular values seem to be too electropositive for the survival of $T$ pallidum, based on our in-vitro studies reported in this paper. $T$ pallidum is known to survive primarily as an extracellular parasite, at least in the early stages of syphilis. Perhaps a redox gradient exists in host tissue, from more electropositive extracellularly to more electronegative intracellularly. A redox potential most suitable to $T$ pallidum may occur at the membrane of the metabolising mammalian cell, thus explaining the enhanced survival of that fraction of exogenously added $T$ pallidum that attaches to cells in tissue culture. ${ }^{3637}$ Of course, other explanations are also possible for this phenomenon (for example, nutritional or enzymic factors), but the role of redox potential is likely to be as important as that of oxygen concentration and nutritional components in future attempts to grow and subculture virulent $T$ pallidum in vitro.

\section{Addendum}

Fieldsteel and co-workers ${ }^{41}$ have just reported the successful cultivation of $T$ pallidum in tissue culture under $1 \cdot 5 \%$ oxygen.

The authors wish to thank Mr F Trewartha and Ms K Prpic for their preliminary work on this project and Ms G Wong for technical assistance. This work was supported by the Heiser Fellowship Program, the National Health and Medical Research Council, the Utah Foundation, and Monash University, from whom funds are gratefully acknowledged.

*To convert $E_{h}$ to $E_{c a l}$ the potential of the saturated calomel electrode, which at $25^{\circ} \mathrm{C}$ and with saturated $\mathrm{KCl}$ is $+241 \mathrm{mV}, 40$ must be taken into account. Thus $\mathrm{E}_{\mathrm{h}}=\left(\mathrm{E}_{\mathrm{cal}}+241\right) \mathrm{mV}$.

\section{References}

1. Fieldsteel A, Stout J, Becker F. Comparative behaviour of virulent strains of Treponema pallidum and Treponema pertenue in gradient cultures of various mammalian cells. Infect Immun 1979; 24:337-45.

2. Sandok P, Jenkin $H$, Matthews $H$, Roberts $M$. Unsustained multiplication of $T$ pallidum (Nichols virulent strain) in vitro in the presence of oxygen. Infect Immun 1978; 19:421-9.

3. Cox C, Barber M. Oxygen uptake by $T$ pallidum. Infect Immun 1974; 10: $123-7$.

4. Lysko P, Cox C. Terminal electron transport in $T$ pallidum. Infect Immun 1977; 16:885-90.

5. Lysko $P$, Cox $C$. Respiration and oxidative phosphorylation in $T$ pallidum. Infect Immun 1978; 21:462-73.

6. Nichols J, Baseman J. Carbon sources utilized by virulent $T$ pallidum. Infect Immun 1975; 12: 1044-50.

7. Schiller N, Cox C. Catabolism of glucose and fatty acids by virulent $T$ pallidum. Infect Immun 1977; 16:60-8.

8. Baseman J, Hayes N. Anabolic potential of virulent $T$ pallidum. Infect Immun 1977; 18:857-9.

9. Baseman J. Nichols J, Mogerley S. Capacity of virulent $T$ pallidum (Nichols) for deoxyribonucleic acid synthesis. Infect Immun 1979; 23:392-7.

10. Nichols J, Baseman J. Ribosomal ribonucleic acid synthesis by virulent T pallidum. Infect Immun 1978; 19:854-60.

11. Barbieri J, Cox C. Glucose incorporation by Treponema pallidum. Infect Immun 1979;24:291-3.

12. Barbieri J, Cox C. Pyruvate oxidation by Treponema pallidum. Infect Immun 1979; 25: 157-63.

13. Baseman $\mathbf{J}$, Hayes $\mathbf{N}$. Protein synthesis by Treponema pallidum extracted from infected rabbit tissue. Infect Immun 1974; 10: 1350-5.

14. Sandok P, Jenkin H. Radiolabelling of $T$ pallidum (Nichuls virulent strain) in vitro with precursors for protein and RNA synthesis. Infect Immun 1978;22;22-8.

15. Fieldsteel A, Becker F, Stout J. Prolonged survival of virulent $T$ pallidum (Nichols strain) in cell free and tissue culture systems. Infect Immun 1977; 18: 173-82.

16. Fitzgerald TJ, Johnson RC, Wolfe E. Mucopolysaccharide material resulting from the interaction of Treponema pallidum (Nichols strain) with cultured mammalian cells. Infect Immun 1978; 22: 575-84.

17. Graves S, Billington T. An optimum concentration of dissolved oxygen for the survival of virulent $T$ pallidum (Nichols strain) under conditions of low oxidation reduction potential. Br J Vener Dis 1979;55:387-93.

18. Norris S, Miller J, Sykes J, Fitzgerald TJ. Influence of oxygen tension, sulphydryl compounds, and serum on the motility and virulence of $T$ pallidum (Nichols strain) in a cell-free system. Infect Immun 1978;22:689-97.

19. Metzger M, Smogor W. Study of the effect of $\mathrm{pH}$ and Eh values of the Nelson-Diesendruck medium on the survival of virulent $T$ pallidum. Arch Immun Ther Exp 1966; 14:445-53.

20. Baseman J, Nichols J, Hayes N. Virulent $T$ pallidum: aerobe or anaerobe. Infect Immun 1976; 13:704-11.

21. Graves S, Sandok P, Jenkin H, Johnson R. Retention of motility and virulence of $T$ pallidum (Nichols strain) in vitro. Infect Immun 1975; 12:1116-20.

22. Stevens KM. Cultivation requirements for $T$ pallidum Mycobacterium leprae, and other microbial and mammalian microaerophilic cells. Medical Hypotheses 1979; 5: 1091-104.

23. Turner TD, Hollander DH. Biology of the Treponematoses. Geneva: WHO, 1957.

24. Morris JG. The physiology of obligate anaerobiosis. In: Rose AH, Tempest DW, eds. Advances in Microbial Physiology. London: Academic Press, 1975; 12: 169-246.

25. Carlsson J, Granberg G, Nyberg G, Exlund M. Bacteriocidal effect of cysteine exposed to atmospheric oxygen. Appl Environ Microbiol 1979; 37:383-90.

26. Chalmers WSK, Robinson DT. The effect of reducing and other agents on the motility of $T$ pallidum in an acellula culture medium. J Gen Microbiol 1979; 114:443-7.

27. Weiss E. Growth and physiology of rickettsiae. Bacteriol Rev 1973;37:259-83.

28. Cross B, Silver I. Neurovascular control of oxygen tension in the testis and epididymis. $J$ Reprod Fertil 1962;3:377-95. 
29. Huch R, Lubbers D, Huch A. The transcutaneous measurement of $\mathrm{O}_{2}$ and $\mathrm{CO}_{2}$ tensions for the determination of arterial blood-gas values with control of local perfusion and peripheral perfusion pressure. Theoretical analysis and practical application. In: Payne J, Hill D. eds. Oxygen Measurements in Biology and Medicine. London: Butterworths, 1975.

30. Frazier $\mathrm{C}, \mathrm{Hu} \mathrm{C}, \mathrm{Ma}$ W. Relation of the changes in testicular structure induced in the rabbit by estrogenic substances to resistance against syphilis. Endocrinology 1941;29:218-24.

31. Chesney A, Turner T, Halley C. Studies in experimental syphilis. VIII On the localization of syphilitic lesions in inflamed areas. Bull Johns Hopkins Hosp 1928; 42:319-34.

32. Lexieux M, Smith R, Couch N. Surface pH and redox potential of skeletal muscle in graded hemorrhage. Surgery 1969;65: 457-61.

33. Rehn J. The clinical significance of the redox potential of the blood. In: The Redox Potential of the Blood in vivo and in vitro: its Measurement and Significance. Springfield, USA: Charles C Thomas, 1965.

34. Grin E, Nadazdin M, Svob M. Effect of hyperbaric oxygen on experimental syphilis in the rabbit. Br J Vener Dis 1973:49: $405-12$.
35. Cater D, Phillips A, Silver I. The measurement of oxidationreduction potentials, $\mathrm{pH}$ and oxygen tensions in tumors. Proc $R$ Soc Lond (Biol) 1956; 146: 382-99.

36. Fitzgerald TJ, Johnson R, Miller J, Sykes J. Characterization of the attachment of Treponema pallidum (Nichols strain) to cultured mammalian cells and the potential relationship of attachment to pathogenicity. Infect Immun 1977; 18:467-78.

37. Fitzgerald TJ, Miller J, Sykes J. T pallidum (Nichols strain) in tissue cultures: cellular attachment, entry and survival. Infect Immun 1975; 11: 1133-40.

38. Coburn R, Ploegnakers F, Gondrie P, Abboud R. Myocardial myoglobin oxygen tension. Am J Physiol 1973; 224:870-6.

39. Shapiro $H$. Redox balance in the body: an approach to quantitation. J Surg Res 1972;3:138-52.

40. Jacob HE. Redox potential. In: Norris JR, Ribbons DW, eds. Methods in Microbiology. London: Academic Press, 1970 91-123.

41. Fieldsteel AH, Cox DL, Moeckli RA. Cultivation of virulent Treponema pallidum in tissue culture. Infect Immun 1981; 32:908-15. 